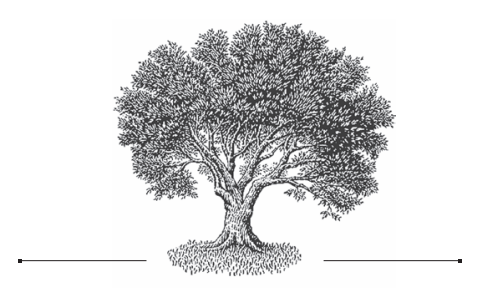

Подьская пародия

на «Отче наш»

середины XVII

века и ее русский

перевод: в поисках

неизвестного

ПОАЬСКОГО

исТОЧнИка

\section{Олена Янссон}

Уппсальский университет

Уппсала, Швеция
A Polish Parody of "Our Father" from the Middle of the 17th Century and its Russian Translation: in Search of an Unknown Polish Source

\author{
Olena Jansson \\ Uppsala university \\ Uppsala, Sweden
}

\title{
Резюме
}

Цель исследования - текстологический анализ русского перевода польского памфлета-пародии на молитву «Отче наш», обнаруженного среди документов Посольского приказа 1671-1673 гг. Источник перевода в архивном деле не найден. Изучение сохранившихся списков польского памфлета “Ojcze nasz krolu polski Janie Kazimierzu" ("Pacierz dworski”) показало, что именно он является оригиналом русского перевода. Эта подьская политическая пародия на молитву, написанная «на случай» и направленная против короля Яна II Казимира Вазы, датируется серединой XVII в. (вероятно, 1665 г.). В статье реконструируется история ее создания, дается формально-содержательная

Цит ирование: Янссон О. Подьская пародия на «Отче наш» середины XVII века и ее русский перевод: в поисках неизвестного польского источника // Slověne. 2018. Vol. 7, № 2. С. 74-104.

Citation: Jansson O. (2018) A Polish Parody of "Our Father" from the Middle of the 17th Century and its Russian Translation: in Search of an Unknown Polish Source. Slověne, Vol. 7, № 2, p. 74-104. 
и жанровая характеристика, обсуждается ее художественная ценность в контексте польской традиции пародирования редигиозных текстов, анадизируются редакции и варианты памфлета. В результате нам удалось пролить свет на новые данные, касающиеся вопросов авторства текста и времени создания сочинения, количества и характера сохранившихся списков, соотношения рукописных вариантов и позднейших их изданий. Сравнительный анализ семи вариантов польского памфлета позволил обнаружить версию, текстуально и, возможно, даже генетически близкую русскому переводу (список из домашней хроники Ширмов “Sylva rerum Szyrmów”). Особое внимание в статье уделяется осмыслению положения подьской переводной пародии в русской культуре середины XVII в., а также возможных причин внимания русского переводчика (читателя) к польскому подитическому памфлету. Результатом трансмиссии подьского текста в Россию становится его функциональная трансформация из политического в «курьезный», с более выразительной смеховой доминантой. В приложении публикуется польский памфлет из домашней хроники Ширмов с разночтениями по другим шести спискам и русский перевод из архива Посодьского приказа.

\section{Ключевые слова}

переводная литература, польская культура XVII в., Посольский приказ, памфлет-пародия, политическая поэзия «на случай»

\section{Abstract}

The purpose of this study is a textual analysis of a Russian translation of a Polish pamphlet, a parody of the prayer "Our Father", which was found among documents from 1671-1673 in the archive of the Ambassadorial Chancery (Posol'skii prikaz). The actual source of the translation was not found, but since any study of a translated text must include an analysis of its connection with the original, it was first of all necessary to pay attention to the known copies of the Polish pamphlet "Ojcze nasz krolu polski Janie Kazimierzu" ("Pacierz dworski"), since one of its now most probably lost copies was translated into Russian. "Ojcze nasz krolu polski Janie Kazimierzu" is a Polish political parody from the middle of the 17th century (probably 1665), directed against King John II Casimir Vasa. The article investigates the history of its creation, describes its form, content, and genre, discusses its literary value, the Polish tradition of parodying religious texts, and analyzes the versions of the pamphlet. As a result, it was possible to reveal some new details about the anonymous author and the time when the work was written, the number and character of the preserved copies, the correlation between manuscript variants and their later editions. A comparative analysis of seven different textual variants of the Polish pamphlet made it possible to find a version which is textually - and perhaps even genetically - close to the Russian translation (a copy of the family saga "Sylva rerum Szyrmów"). Particular attention is paid to the interpretation of Polish translation parody in mid-17th century Russian culture, the possible reasons why this Polish political pamphlet caught the attention of the Russian translator (reader), and the functional transformation of the occasional political pamphlet into a parody with a political theme and a more explicit humoristic component. The appendix provides a parallel publication of the Polish pamphlet from the family saga "Sylva 
rerum Szyrmów" and the Russian translation from the archive of the Ambassadorial Chancery.

Keywords

translated literature, Polish culture of the 17th century, Ambassadorial Chancery (Posol'skii prikaz), pamphlet-parody, political occasional poetry

\section{Введение}

В истории русской культуры XVI-XVIII вв. особое место занимают переводы с польского языка, каталог которых наиболее полно представлен в библиографическом справочнике С. И. Николаева [Николаев 2008]. Этот список можно дополнить, в частности, благодаря работам русского историка С. М. Шамина, который ввел в научный оборот другие переводные памятники XVII в. Одним из них является памфлетпародия «Отче наш кроле польский Яне Казимере», обнаруженный среди документов Посольского приказа 1671-1673 гг. и опубликованный исследователем [Шамин 2011]. Архивное дело хранится в Российском государственном архиве древних актов, в фонде, где собраны куранты обзоры европейской прессы [РГАДА155]. Памфлет, однако, не относился к курантам, а, скорее всего, был частью личного архива кого-то из приказных служащих [Шамин 2011: 108].

Памфлет-пародия на молитву «Отче наш» направлен против короля Яна II Казимира Вазы. Иронический и сатирический тон в нем рождается благодаря контрасту между текстуальными реминисценциями сакральной молитвы «Отче наш» и профанным содержанием - осуждением политики короля и жалобами на экономическую ситуацию в Польше середины 1660-х гг. Это сатирическое произведение «на случай» ${ }^{1}$ типично для того времени: «...сатира [...] - совершенное проявление чувств, которыми пылало общество к тем, кого считало виновником своих невзгод» [Hniłko 1910: 2].

Польского источника в архивном деле не было, поэтому С. М. Шамин, анализируя памфлет как исторический документ, полностью сосредоточил свое внимание на русском тексте. Импульсом для нашего исследования послужило убеждение в том, что для осмысления перевода необходимо сопоставление с оригиналом и осмысление культурного

1 В польском литературоведении вместо термина «поэзия на случай» употребляется термин «окказиональная поэзия». Этот же термин в указанном значении обычно использует и упомянутый выше исследователь С. И. Николаев, основной специалист в России в области польской поэзии XVII-XVIII вв. и ее русских переводов. В нашей публикации по предложению редакции данного журнала отдается предпочтение термину «поэзия на случай», так как под окказиональной поэзией традиционно понимается поэзия панегирическая, торжественная. 
контекста возникновения обоих текстов. Наша публикация отражает результаты изучения истории создания произведения, выявления списков, генетически связанных с неизвестным польским источником, их описания, анализа текстологических особенностей русского перевода в его соотношении с параллельными версиями польского текста. Всё это дает возможность получить представление о ненайденном польском источнике.

\section{1. Польский оригинал}

Из заглавия русского перевода известно, что источником для него послужил польский рукописный, а не печатный текст, так как в начале его указано: «перевод с польского письма». С. В. Алпатов и С. М. Шамин показали, что в Посольском приказе переводы делались как с печатных, так и с рукописных памфлетов из Речи Посполитой, в том числе с произведений юмористического содержания [Алпатов, Шамин 2013: 2729]. Оригинал, если он не сохранился в одном деле с переводом, выявить удается не всегда. В нашем случае, однако, было достаточно обратиться к сборникам памфлетов историка польской литературы Ю. НовакаДлужевского. В 1953 г. он опубликовал польский памфлет середины XVII в. "Pacierz dworski” (“Ojcze nasz, królu polski, Janie Kazimierzu”) [NowakDłużewski 1953: 181], который соотносится с исследуемым русским переводом, однако не совпадает с ним полностью. В примечаниях НовакДлужевский указал, что в 1853 и 1858 гг. были изданы два рукописных варианта этого текста ${ }^{2}$, которые, как видим, входили в состав мемуарных записей-хроник типа диариуша. Судя по выводам ученого, печатных версий этого памфлета не существовало. Отчасти это могло быть следствием распространенности рукописной традиции в XVII в. Основной же причиной следует, скорее всего, считать то, что, как отмечает Новак-Длужевский, политическая поэзия избегала печати, поскольку как авторы, так и издатели политических сочинений могли навлечь на себя репрессии [Ibid.: XVII]. Однако памфлет активно распространялся в составе рукописных кодексов в ряду других политических сатир и пародий и, возможно, в виде рукописных летучих листков.

Ю. Новак-Длужевский дал ссылки на восемь списков “Ojcze nasz”, но в свое издание включил только три из них, а для остальных в сноске был указан только шифр. Интересно отметить, что именно эти три рукописи - BK316; BK361; Bran42/56 - пережили Вторую мировую войну и были найдены нами в польских архивах ${ }^{3}$. Важно отметить, что Новак-

2 В 1853 г. издателем К. Вуйчицким в составе мемуаров Я. Ерлича, а в 1858 г. издателем Ж. Паули как приложение к мемуарам Я. Лося.

3 Остальные пять были утрачены. Проверка указанных исследователем шифров осложнялась тем, что во многих случаях они отсылали к не существующим 
Длужевский напечатал в своем сборнике «составной» памфлет по двум разным спискам: строки 10, 19 и 28 из Bran42/56 были заменены на «более правильные», с его точки зрения, строки из версии ВКЗ61. Подобный вариант текста, таким образом, не встречается ни в одной из сохранившихся польских рукописей. Это значит, что все, кто цитирует текст по изданию Новака-Длужевского, по сути обращаются к его авторской версии ${ }^{4}$. Таким образом, самыми новыми публикациями бытовавших в народе списков памфлета должны быть признаны издания 1853 и 1858 гг. ${ }^{5}$

Кроме восьми списков, известных благодаря Новаку-Длужевскому, в научной литературе есть ссылки еще на два - BUW74; BCzart1861. Они указаны Я. Хорошим, составившим хрестоматию переводов, переделок и иных литературных обработок молитвы “Ojcze nasz” в Польше [Choroszy 2008, II: 7, 577]. Еще один список обнаружен нами в домашней хронике Ширмов (“Sylva rerum Szyrmów” [R113])6. Именно он, как оказалось, является текстуально и, возможно, даже генетически наиболее близким к русскому переводу.

К общему перечню списков можно бы было добавить две опубликованные копии памфлета, но фактически мы приплюсовываем только одну. В результате сравнения издания 1858 г. с рукописью ВК316 нами установлено, что издание дословно отражает указанный список, и не исключено, что именно он и был использован издателем Ж. Паули․ Таким образом, печатное издание 1858 г. не увеличивает общего количества списков.

сегодня учреждениям, поиск которых требовал изучения истории польских архивов и библиотек. Например, оказалось, что шифр Biblioteka w Suchej 56 принадлежал ныне несуществующей Библиотеке Браницких, рукописи которой, сохранившиеся после Второй мировой войны, были переданы в Главный архив древних актов в Варшаве (Archiwum Główne Akt Dawnych), шифр Bran42/56.

4 Разумеется, нет оснований полностью отрицать возможность существования и такой версии текста, но пока эта гипотеза не подтверждена найденными списками.

5 Вышедшее в 1916 г. киевское издание до самого последнего времени было недоступным для читателей и до сих пор остается неизвестным как польским, так и российским исследователям. Это самое полное на сегодняшний день издание, в основе которого лежит рукописный список наследника Ерлича Я. Ваксмана, сделанный, по его утверждению, с автографа автора. Последним местом хранения протографа считается Библиотека Красинских в Варшаве, сгоревшая в 1944 г. Издание было подготовлено к публикации О. Левицким в 1916 г. в Киеве, но почти все экземпляры, кроме одного, погибли во время Гражданской войны 1917-1921 гг. Издание Левицкого учитывает разночтения по изданию К. Вуйчицкого и рукописи Ваксмана, а также содержит стихи, напечатанные Н. И. Костомаровым по мемуарам Ерлича, но исключенные из текста Вуйчицким и Ваксманом.

6 Сборник детально описан в статье: [Zachara 1981].

7 Подробнее об этом см. в разделе «7. Текстологические особенности польского памфлета». 
В целом можно утверждать, что в Польше существовало как минимум двенадцать рукописных списков этой пародии, семь из которых сохранились до наших дней и были использованы нами при подготовке статьи. Русский перевод открывает нам еще одну, неизвестную для польского читателя, версию этого памфлета.

\section{2. К вопросу об анонимном авторе и времени создания польского памсфлета}

Основные сведения об авторе и времени написания памфлета дает в краткой характеристике Ю. Новак-Длужевский [Nowak-Dłużewski 1972: 300-301]. Во-первых, исследователь отмечает, что, поскольку один из списков памфлета, хранившийся в Национальной библиотеке Польши ${ }^{8}$, имел название "Pacerz opatowskiego sejmiku", можно предположить, что он «был создан очевидно в среде сандомерской шляхты, собирающейся на провинциальные сеймики в Опатове» [Ibid.: 300]. Также Новак-Длужевский, коротко ссылаясь на «Летописец» Я. Ерлича (“Latopisiec albo Kroniczka różnych spraw i dziejów...”), указывает точную дату создания пародии: 1665 г. В мемуарных записях шляхтича Яна (Иоакима) Ерлича", охватывающих события 1620-1673 гг. действительно содержится текст пародийной молитвы “Oycze nasz królu Polski Kazimierzu”, а также другие стихи, песни, памфлеты и документы. Оригинальная рукопись, как и ее списки, к сожалению, погибли в начале XX в. Однако мемуары Ерлича были опубликованы в двух разных изданиях: К. Вуйчицкого [Jerlicz 1853: 103-105] и О. Левицкого [Ерлич 1916]. Последнее, судя по всему, не было известно Новаку-Длужевскому. Первый издатель, К. Вуйчицкий [Jerlicz 1853: 103-105] опирался на поздний (XVIII в.) список с мемуаров Ерлича из коллекции Я. Альбертранди, которая погибла во время Первой мировой войны в Ростове-на-Дону вместе с эвакуированными туда другими рукописями Библиотеки Варшавского университета [Яковенко 2012: 71]. В обоих изданиях текст пародии неполный, но Левицкий, в отличие от Вуйчицкого, не модернизирует правописание списка.

«Пасквиль» на Яна Казимира, как обозначил этот жанр в своих мемуарах Ерлич, сопровождается вводным замечанием: «...написан в военном лагере и подброшен в палатку при отправлении службы» [Ерлич 1916: 284]. Интересно, что похожая интерполяция-комментарий по поводу места написания сопровождает и другой, более ранний памфлет, вставленный в «Летописец», - на канцлера Ю. Оссолинского 1650 г.: «...пасквиль написан в военном лагере под Зборовом» [Возняк 1931:

8 По свидетельству библиотекарей, эта рукопись сгорела в октябре 1944 г.

9 Родословную и биографию Я. Ерлича см. в: [Тесленко 2004]. 
202]. Такие ремарки не только подчеркивают желание автора зафиксировать в дневнике известные ему детали появления памфлетов, но также, судя по другим мемуарным источникам, являются традиционным способом введения поэзии «на случай» в повествовательную структуру записок. О каком военном лагере идет речь в комментарии к “Ojcze nasz", Ерлич, к сожалению, не указал.

Конкретной даты Ерлич также не сообщает, но информацию о памфлете он размещает после описания ключевого события «рокоша Любомирского» (военной конфедерации 1665-1666 гг. под руководством гетмана польного коронного Ежи Любомирского, выступившего против короля Яна II Казимира Вазы) - а именно, после записи от 5 сентября 1665 г. ${ }^{10}$, в которой описывается сентябрьская битва под Ченстоховой. Она написана постфактум, так как содержит упоминание о том, что произошло с пленными через две недели после битвы. Следующая запись дневника, помещенная уже после памфлета, не нарушает общую хронологию и датируется 15-16 сентября 1665 г. (в ней описывается смерть племянницы Ерлича Ганны). Таким образом, исходя из записей Ерлича, можно было бы предположить, что памфлет “Ojcze nasz” был создан между 5 и 15 сентября 1665 г. в военном лагере рокошан под Ченстоховой (или подброшен туда).

Однако нужно иметь в виду, что автор дневника не был очевидцем описываемых событий: в то время ему было уже 67 лет и он постоянно проживал на Волыни со своей семьей [Тесленко 2004: 173-174]. И. Тесленко предполагает, что известия о военных действиях Ерлич мог получать от своих сыновей [Ibid.: 164]. Уточнить, каким путем памфлет "Ojcze nasz" попал в руки Ерлича, скорее всего, не удастся. Поскольку считается, что Ерлич в это время довольно регулярно вел свой дневник, можно предположить, что памфлет попал к нему в руки той же осенью 1665 г. Утверждать, что сам Ерлич мог быть автором поэтических вставок, нет оснований ввиду разнохарактерности их стилистики, низкой художественной ценности самих записок Ерлича и общего компилятивного характера его дневника, включающего намного больше заимствованного, нежели лично созданного материала ${ }^{11}$. Гипотезу НовакаДлужевского о связи пародии с Опатовским сеймиком, скорее всего, не удастся ни подтвердить, ни опровергнуть: рукопись, в которой памфлет “Ojcze nasz" имел такой заголовок, к сожалению, не сохранилась.

В литературе встречается также другая дата создания памфлета 1668 г. Источником этой (на первый взгляд, ошибочной) даты является

10 В издании К. Вуйчицкого ошибочно вместо 5 сентября указана дата 5 октября, после которой странным образом появляется 15-16 сентября.

11 Характеризуя мемуары Ерлича, польский историк Ю. Бартошевич заявлял: «Здесь нет никакого таланта» [Bartoszewicz 1877: 26]. 
текст пародии на “Ojcze nasz”, найденный среди мемуаров «Записки Лося» (“Pamiętniki Łosia”). В первом издании мемуаров шляхтича и панцирного казака Якуба Лося в 1858 г., в конце основного текста воспоминаний, действительно есть два поэтических дополнения, одним из которых является памфлет “Ojcze nasz królu polski Janie Kazimierzu”. В печатном издании он не имеет заголовка, но размещен под рубрикой “Wiersze o panowaniu króla Jana Kazimierza 1668”, названной так, по-видимому, издателем Жеготой Паули. Здесь текст пародии имеет несколько другое окончание, упоминающее отречение короля от престола, а значит - дописанное после сентября 1668 г. В предисловии Ж. Паули указал, что поэтические и документальные дополнения к тексту дневника подобраны им самим «для лучшего разъяснения некоторых запутанных отношений в тогдашней Польше» [Pamiętniki 1858: XX]. Новак-Длужевский считал, что «дата создания произведения установлена у Лося ошибочно как 1668 год» [Nowak-Dłużewski 1953: 181]. На наш взгляд, 1668 год соответствует дате появления более поздней версии текста. Но по отношению к фразе «дата появления памфлета» она, конечно, несправедлива. Кроме того, мы видим, что указанный год проставлен в памфлете не Лосем, а издателем его воспоминаний Паули, который, в свою очередь, мог позаимствовать его из рукописи. В том, что эти поэтические приложения отсутствуют в самих мемуарах Лося, убеждает нас также их оригинал, найденный и опубликованный Р. Сьренявой-Шипёвским [Łoś 2000].

Информация о том, что памфлет-пародия “Ojcze nasz” является дополнением, сделанным не самим Якубом Лосем, а издателем его записок, была упущена, как мы можем наблюдать, не только Новаком-Длужевским, но и другими, в том числе современными, исследователями. Памфлет-пародия на Яна Казимира с датой 1668 г. цитируется, например, в исследованиях по экономической истории Польши - в частности, по нумизматике [Hniłko 1910; Dziewanowski-Stefańczyk 2017] ${ }^{12}$. Связь анализируемого памфлета с нумизматикой объясняется содержащимся в нем пассажем, направленным против денежных реформ Т. Л. Боратини и А. Тымфа ("Ale nas zbaw od Tynfa i Boratyniego / I poszlij ich do czarta, piekła przeklętego...” ${ }^{3}$ ). В экономических и исторических трудах эти строки

12 Отметим, что в научно-популярной статье Дзевановского-Стефанчика процитированный полностью текст памфлета «Отче наш» приобрел новую, модернизированную форму - не только в орфографии и пунктуации, но и в содержании: автор или редактор журнала выбросили некоторые «ненужные» слова из версии издателя записок Лося 1858 г., «улучшив» версификацию. Таким образом, памфлет продолжает свою жизнь как многовариантное фольклорное произведение.

13 Цит. по изданию “Pamiętniki Łosia” 1858 г. [Pamiętniki 1858: 117], поскольку в указанных исследованиях использовано именно это издание. Перевод основного текста памфлета см. в приложении. 
призваны проиллюстрировать негативное отношение поляков к правлению Яна Казимира.

Издание “Pamiętniki Łosia” 1858 г. положило начало дискуссии о Владиславе Лосе (не Якубе - составителе мемуаров) как авторе памфлета [Hniłko 1910: 2]. Подобный вывод опирался на гипотезу Ж. Паули о том, что «Записки Лося» написал стольник Владислав Лось. Однако позднее было доказано, что их автором был его однофамилец - Якуб [ŚreniawaSzypiowski 2000].

\section{3. Формально-содержательная характеристика пародии "Ojcze nasz"}

В памфлете-пародии “Ojcze nasz królu polski Janie Kazimierzu” отсутствуют сложные барочные метафоры, латинизмы и другие признаки, выявляющие в этот период художественную эрудицию автора. Однако в тексте ярко проступает ирония и даже сарказм при контаминации цитат из молитвы с реалиями времен правления Яна Казимира. Например, уже приведенное выше осуждение реформ Т. Л. Боратини и А. Тымфа строится на замещении лексемы “złego” из канонического текста молитвы именами организаторов реформы: “Ale nas zbaw ode złego"14 превращается в “Ale nas zbaw od Tymfa, y Buratyniego” (29) ${ }^{15}$. Такие примеры сконцентрированы в первой части памфлета, а вторая, за исключением указанной строки о реформах, исчерпав лексические средства пародийного заимствования из молитвы, обращается к прямым, лишенным аллюзийности советам королю по исправлению ситуации в стране: “Роtrzeba znowu kazac, bic czerwone złote...” (31), "Każ znowu dobre robic talary y orty" (33), "Przywroc do Korony tesz srebro y złoto...” (35).

Некоторое мастерство нужно признать за автором в области версификации: памфлет “Ojcze nasz” - пример рифмованного и относительно стабильного в разных его вариантах польского 13-сложника, который в конце произведения сменяется восьмисложником. Полные версии памфлета состоят из 40 стихотворных строк, разбитых на двустишия. Первая строка, как правило, пародирует текст молитвы, а вторая - расширяет или дополняет тезис, заявленный в пародийной, часто развивая его в аллюзию на современную политико-экономическую ситуацию, например, на Шведскую и прошведскую политику короля: "Bądz wola twoia iako Wandalu była. / Gdzie słyszem chleba mało a śledzi siła” (7-8).

14 Молитва цитируется по одной из версий, лексически близких к памфлету: ср.: Biblia Leopolity, Mt 6, 9-13 [Choroszy 2008, I: 48].

15 Здесь и далее, если нет других указаний, памфлет цитируется по рукописи $R 113$, поданной в приложении; в скобках указывается номер строки. 
Начиная с девятого двустишия текст все более расширяется параллельными ассоциациями: к примеру, строка "Nie wodź nas na woyne z Szwedy z Francuzami” (15) продолжается еще двумя пожеланиями в строках "I nie wprowadzaj nam też na państwo Francuza” (17) и “A ni nam tesz racz więcey zyczyc Kondeusa” (19). Далее автор текста возвращается к религиозной тематике и лексике, соединяя при помощи рифмы всемогущего Бога и фамилию Любомирского в одном двустишии и таким образом четко показывая свои политические приоритеты:

Panuy nam poki wola Boga wszechmocnego. /

Przyiąwszy zas do łaski swej Lubomirskiego (21-22).

Начиная со строки 23, автор памфлета обращается к осуждению конкретных политических фигур - приверженцев короля (и противников Любомирского), фамилии которых находим во многих памфлетах и личных письмах сторонников рокоша: Миколая Пражмовского, Владислава Рея, Яна Гнинского, Миколая Паца. В строках 27-36 осуждаются денежные реформы Т. Л. Боратини и А. Тымфа и даются советы, как улучшить экономическую ситуацию в стране. В последних четырех строках автор клеймит всех врагов, употребляя общее "zdrayce", адресованное, очевидно, как вышеуказанным, так и всем другим своим врагам, и возвращается к молитвенному “Amen”.

\section{4. Жанр текста}

В нашей статье уже встречалось определение исследуемого произведения как памфлета, пародии и сатиры ${ }^{16}$ в качестве взаимозаменяемых понятий. По сути, каждый термин подчеркивает разные стороны анализируемого текста:

памфлет - его политическую направленность;

пародия - его структурную специфику, заключающуюся в следовании формально-содержательным особенностям молитвы "Ojcze nasz" (нанизывание социально-политического содержания на молитвенные формулировки);

сатира - особенность содержательной и пафосной характеристики текста. Сатира как вид комического в памфлете “Ojcze nasz” выражается преимущественно в форме гипербол, иронического контраста, пародирования одного из самых священных текстов, соотносящегося с сакральным дискурсом (так называемой "parodia sacra” ${ }^{17}$ ) и дискурсом

16 В цитатах употребляется также устаревший термин «пасквиль», подчеркивающий резкость выпадов в адрес короля.

17 Осознавая проблемность термина “parodia sacra”, раскрытую в статье М. Бурде [Burde 2010: 223], все же считаем целесообразным анализ нашего памфлета в рамках общепринятой в литературоведении бахтинской концепции «священной пародии». 
власти. Сатирический пафос и народная смеховая культура сближают анализируемую пародию с совизжальской литературой ${ }^{18}$.

Нужно подчеркнуть, что анонимная поэзия «на случай» имеет самую тесную связь с народной смеховой культурой своего времени, которая еще не до конца раскрыта и исследована. Возможно, именно дух всенародности, свойственный как карнавалу, так и военным действиям, становится толчком к множественным политическим пародиям и сатирам, создававшимся в период конфедераций и различных военно-политических и социальных конфликтов.

Появление нашего стихотворения вызвано военными событиями рокоша Любомирского. В нем отражены и другие военные конфликты Польши: "Nie wodź nas na woyne z Szwedy z Francuzami / Gdyz mamy dosyc zabawki z Moskwą Kozakami” (15-16). Это вводит его в дискурс военной (солдатской) поэзии XVII в.

\section{5. Несколько слов о художественной ценности паморлета}

В оценке роли и художественной ценности анонимной поэзии «на случай» в целом и пародий на религиозные молитвы в частности можно отметить некоторое расхождение. С одной стороны, П. Петшик указывает на низкую художественную ценность пародий XVII и XVIII вв. изза отсутствия литературной эрудиции у их авторов [Pietrzyk 2008]. C другой стороны, Ю. Новак-Длужевский, противопоставляя анонимную политическую поэзию официальной, представленной всем известными именами писателей, отмечает «ее широту и буйность, смелость и размах использованных в ней литературных форм, которые и не снились современной ей официальной литературе, литературную изобретательность в приспособлении формы к содержанию поэтических шаржей, несравненное красноречие в развитии литературного замысла...» [Nowak-Dłużewski 1967: 157]. Однако применительно к нашему тексту эти характеристики скорее дополняют друг друга. Анонимный автор изучаемого памфлета, очевидно, пользовался более ранним примером подобной пародии, заимствуя значительную часть как религиозных, так и социально-политических аллюзий (о чем пойдет речь ниже), однако, на наш взгляд, это не уменьшает художественной ценности его произведения.

18 Понятие совизжальской литературы (от имени Совизжал, польского варианта имени Эйленшпигеля) охватывает творчество «плебейских юмористов» выходцев из мелкой шляхты, низшего духовенства, горожан, студентов - и противопоставляется шляхетской и мещанской литературе. Совизжали часто пользовались художественными средствами пародии, сатиры и карикатуры для высмеивания высших слоев общества или просто для развлечения, смеха ради смеха. О совизжальской литературе см. подробнее, например: [Grzeszczuk 1966]. 
6. Памсрлет "Pacierz dworski" и польская традиция

пародирования религиозных текстов

Пародирование библейских и богослужебных текстов, даже таких сакральных, как “Pater noster" и “Ave Maria”, восходит к латинской литературе странствующих школьников и монахов [Адрианова-Перетц 1936: 335]. Распространившись благодаря французским голиардам, сатира в форме молитв стала популярной в Западной Европе во времена реформации, а в Польше - в XVI в. Исследование Ю. Новака-Длужевского показывает, что большинство польских пародий на религиозные тексты имело политическую направленность: «Начиная с XVI в. и почти до последних лет XVIII в. старопольская политическая поэзия существовала в форме пародий религиозных текстов» [Nowak-Dłużewski 1967: 168]. При этом ученый приводит много примеров «рокошевых» пародий сочинений, возникших в период наиболее активного противостояния народа польским властям - военных мятежей («ро́кошей»). Таким образом, пародирование религиозных текстов имело не только литературное, но и общественное значение.

Пародии на молитву «Отче наш» (как анонимные, так и авторские) распространяются в Польше в XVI-XVII вв. на латинском, немецком и польском языках. Большинство из них имели яркую политическую направленность. При этом анонимные пародии «на случай», циркулируя в обществе как часть фольклорной памяти, становились основой культурного взаимодействия между разными социальными группами и разными поколениями польского народа. Они часто возникали в результате прямого заимствования формально-содержательных характеристик полюбившихся образцов в процессе адаптации их к новым социальнополитическим условиям. Р. Кшивы считает сущностной характеристикой этих текстов имитационность [Krzywy 2018: 11]. Анализируемая нами пародия является звеном в цепочке таких многократных рецепций и адаптаций.

В главе «Религиозные формы старопольской политической поэзии» Ю. Новак-Длужевский указывает на пример троекратной однотипной адаптации молитвы «Отче наш»: первый раз во времена Сигизмунда III, в начале XVII в., под названием "Pacierz do Króla Jegomości”; второй "Pacierz dworski" в середине XVII в.; третий - "Pacierz skomponowany w Warszawie 1729 od pewnego katolika”, адресованный королю Августу II. При этом исследователь отмечает, что «сигизмундовская редакция повторяется в казимировской и августовской не только в порядке использования слов Молитвы Господней, расположенных в каждой паре строк, но также и в способе интерпретации молитвенных строф с помощью тех же самых выражений и оборотов» [Nowak-Dłużewski 1967: 169]. 
Уточним, что "Pacierz do Króla Jegomości” (“Ojcze nasz, królu polski, który mieszkasz w Warszawie”), по мнению Я. Чубека, был создан во время Люблинского съезда в июне 1606 г. участником рокоша Зебжидовского восстания шляхты против короля 1606-1609 гг. [Czubek 1916]. А третий памфлет под названием "Pacierz do króla Augusta” (“Ojcze nasz, królu pański, o Auguście wtory”) связывается с тарногродской конфедерацией 1715-1716 гг. [Choroszy 2008, II: 579].

Кроме этого, Ю. Новак-Длужевский в антологии "Poezja Związku Święconego i rokoszu Lubomirskiego” указал на связь анализируемого нами памфлета еще с одной пародией, которую исследователь определил как иную версию того же текста. Этому определению можно небезосновательно возразить. Первая часть пародии "Pacierz dworski Vivente Joanne Casimiro et uxore illius Maria Ludovica” [Nowak-Dłużewski 1953: 181-183] действительно является переделкой памфлета "Pacierz dworski” и в одном из списков, согласно сведениям ученого, даже имеет название "Рacierz Korony Polskiej drugiej kompozycyjej 1666” [Ibid.: 181]. Однако вторая и третья часть этого более развернутого текста (62 строки) имеют самостоятельные названия (“Ave Maria” и "Credo in unum Deum”) и, соответственно, пародируют тексты других молитв. Впрочем, даже первая часть текста носит следы глубокого авторского переосмысления и стилистической переработки текста, что дает основания определить его не как версию памфлета "Pacierz dworski”, а как относительно самостоятельное звено в цепочке пародий на «Отче наш». Начало же этой подражательной цепочки, возможно, даже более раннее, чем памфлет 1606 г. В сборнике М. Хлопицкого, в котором также размещен один из списков исследуемого памфлета, есть “Modlitwa mazowiecka święta” (Святая мaзовецкая молитва), датируемая приблизительно концом XVI в. ("przed r. 1586?”'19). Ее текст включает в свою антологию и Я. Хороший, называя эту пародию «самой ранней молитвой среди окказиональной и сатирической литературы в Польше» [Choroszy 2008, II: 573]. В отличие от вышеуказанных пародий, эта - прозаическая и меньше по объему, но здесь мы находим, к примеру, отразившийся потом в других текстах зачин: “Ojcze nasz, królu Batory, ktoryś...”, а также повторяющееся во всех произведениях упоминание о налогах: “...odpuść na <m> łanowe, czopowe, bykowe...” ${ }^{20}$. Интересно отметить закономерное увеличение объема указанных

19 См. описание сборника "Zbiór mów, listów oraz satyr i pamfletów politycznych, sporządzony przez Michała Chłopickiego skarbnika żydaczowskiego, w latach 17001709” в каталоге библиотеки Чарторыйских: http://sowwwa.muzeum.krakow.pl, последнее обращение: 28.11.2018. Здесь находится и указанная датировка.

${ }^{20}$ Имеются в виду лановая, чоповая и быковая подати. Ср. памфлет 1606 г.: “Odpuść nam łanowe, poborowe, czopowe"; памфлет 1665 г.: "Odpuść nam nasze winy, pogłówne, rogowe”; памфлет 1716 г.: "Odpuść nam nasze winy, podatki, dymowe”. 
текстов (начиная с памфлета 1606 г. - соответственно 19, 40 и 118 строк), связанное с ростом влияния прозаических жанров, что, в свою очередь, структурно дистанцирует их от молитвенного архетипа.

Наиболее тесная связь, однако, существует между анонимной пародией “Pacierz do Króla Jegomości” 1606 г., обращенной к королю Сигизмунду III Вазе, и памфлетом “Pacierz dworski” 1665 г., адресованным Яну Казимиру. Первая часть изучаемого нами памфлета заимствует из пародии начала века целые фразы и даже строки: 46 из 98 лексем памфлета начала века повторяются в памфлете середины века, но 21 лексема из них в обеих пародиях общие с библейским текстом молитвы. Поэтому создается впечатление, что автор «казимировской» пародии имел перед собой или знал наизусть текст «сигизмундовской» ${ }^{21}$. Ответ на вопрос, каким образом возникла эта связь, вряд ли можно ограничить высказыванием Ю. Новака-Длужевского о большой популярности «сигизмундовской» пародии, которая «сохранила свою свежесть, чтобы возобновиться в новом политическом содержании» [Nowak-Dłużewski 1967: 169]. Как представляется, некоторую роль в этом совпадении играет их общий, судя по имеющимся сведениям, регион возникновения - югозападная часть Польши, а также участие во всех трех упомянутых рокошах сандомерской шляхты. Однако, поскольку информация о местах создания этих текстов не подтверждена документально, опираться на нее приходится с большой осторожностью.

\section{7. Текстологические особенности польского памфолета}

Из известных нам семи вариантов памфлета "Pacierz dworski” шесть сохранились в рукописных сборниках и один, записанный в «Хроничке» Ерлича, дошел до нас только в печатном виде. Второй изданный вариант памфлета, как уже упоминалось выше, дословно совпадает с текстом в рукописи $B K 316^{22}$. Этого, очевидно, не заметил Ю. Новак-Длужевский, комментируя обе публикации текста как «неточные и со множественными предметными ошибками» [Nowak-Dłużewski 1953: 181], но при этом лично ссылаясь на список ВК316. Как в издании «Записок Лося» К. Вуйчицкого, так и в более исправном издании О. Левицкого памфлет Ерлича имеет всего 24 строки (полный текст содержит 40 строк). Он характеризируется множественными пропусками слов: даже в самом названии “Oycze nasz królu Polski Kazimierzu” выпущено имя короля.

21 Определения «казимировская» и «сигизмундовская» даны Новаком-Длужевским. По сути, нужно говорить об антиказимировской и антисигизмундовской пародиях.

22 Вопрос, использовал ли издатель Ж. Паули именно рукопись ВК316, требует дальнейшего исследования. 
Текст памфлета у Ерлича во многом отличается от других известных нам его версий. Бытовал ли этот сокращенный вариант на самом деле, сокращен ли текст при первичной его записи или при вторичной обработке переписчиками и издателями ${ }^{23}$, неизвестно.

Довольно четко можно выделить ранние редакции памфлета и по крайней мере одну позднюю (в рукописи $B K 316)^{24}$, созданную после отречения Яна Казимира от престола в 1668 г. Два из семи списков (BK361 и $B U W 74)$ имеют, соответственно, 34 и 36 строк и не содержат завершающих двустиший, представленных в остальных списках, к примеру:

A zdraycy wezmą zapłatę

Za takową wielką stratę

Amen Amen mily Panie.

Niech ze sie to wrychle stanie [Bran42/56].

Этот же вариант окончания - в R113 и в BCzart1861. Однако в BCzart1861 первые две строки имеют вид 13-сложника, и в них содержится указание на причастность автора этой версии (а возможно, и всего памфлета) к «коронной шляхте»: “I straisi z waszeciami, wezmą swą zaplatę / Za taką nas koronnych szlachty wielką stratę”. В «Хроничке» Epлича эти строки сокращены до "O móy miły panie! / Niech że się tak stanie! - Amen” [Ерлич 1916: 285]. А редакция, созданная после отречения короля 1668 г., вместо этого оканчивается двустишием:

Już o to wszystko trudno. Pacierza nie sprostał,

Uczyc się od Polakow, Abdykantem został [BK316].

При сравнении семи вариантов текста бросается в глаза частая вариативность служебных частей речи, местоимений и прилагательных, нередко ограничивающаяся изменением их места в строке, иногда глагольная синонимия. Так, в строке 18 имеем вариацию "wielkiego/ciężkiego/takowego guza”, в строке 21 - "Boga wszechmocnego/najwyższego", а строка 20 перефразируется еще чаще:

Gdyż go cale nie lubi strasznie nasza dusza [Bran42/56],

Gdyż go strasznie nie lubi cale nasza dusza [R113],

Gdyż go cale nie lubi nasza Polska dusza [BK316] и др.

${ }^{23}$ Кроме современной орфографии, К. Вучицкий, как мы видим при сравнении с изданием О. Левицкого, исправил по своему усмотрению словоупотребление, переставив местами в половине строк слова или изменив их форму (не считая случаев модернизации правописания, исправления внесены в 12 из 24 строк).

${ }^{24}$ Текст памфлета в рукописи $B K 361$, возможно, тоже является более поздней редакцией, поскольку он очень близок к тексту BK316. Однако в BK361 отсутствует завершающая часть, по которой можно бы было сделать окончательный вывод. 
Содержательных изменений в исследуемых вариантах не наблюдается, но резкость выпадов варьируется. Например, вторая часть двустишия "Ale nas zbaw od Tympha y Boratyniego / I racz onych odesłać do Woyska Związkowego" (Bran42/56; этот же вариант - в BCzart1861, $R 113, B U W 74^{25}$ ) в других версиях заменена на "I poszli ich do czarta piekła przeklętego" (ВK316; тот же вариант - в BK361 и в «Хроничке» Ерлича). Ю. Новак-Длужевский, кстати, считал строку "I racz onych odesłać do Woyska Związkowego” ошибочной, поскольку в двух из трех использованных им списков ${ }^{26}$ и в напечатанных вариантах у Ерлича и Лося был предложен второй вариант, с упоминанием черта [NowakDłużewski 1953: 292].

Списки памфлета в рукописях BK316 и BK361 имеют многие общие характеристики, не встречающиеся в остальных списках, что, возможно, указывает на их происхождение от общего источника, тем более что BK361 озаглавлен “Соріа Pacierza”. Так, в обоих списках отсутствуют строки о Гнинском (строки 25-26 в полных версиях); строка 32, которая в других вариантах звучит "A zagubić szelągi, francuską niecnotę” (с вариацией "i francuzską cnotę"), оканчивается здесь на "przemierzłą robotę / holotę" (BK361 / BK316), а строки 33-34 вместо "talery i orty”, рифмующихся с "sorty" или "kąty”, предлагают вариацию "orty i talery”, рифмуя последние с "Polscy kawalery” (BK316) или, с видимой частичной потерей рифмы, - "jak przedtem bywaly" (BK361). Интересно, что в версии Ерлича имеется такая же замена в этом двустишии, где рифмуются "orty i talary” и "za innych bywały”. Сравнив два последних списка, можно предположить ошибку или намеренное исправление рифмы "talery - bywaly" переписчиком в BK361 (очевидно, должно быть "talary - bywaly"). Этот случай является одним из примеров вариативности форм talar / taler в польском языке XVII в.

Структура пародируемой молитвы, как нам кажется, определяет степень вариативности текста памфлета: чем больше он начинает отдаляться от молитвенного архетипа, тем большая вариативность отмечается в разных его версиях. Во второй части стиха наблюдается не только замена, но и пропуск отдельных двустиший как в основном тексте, так и в концовке. Подвижная вариативная природа памфлета дает основания предположить, что он вошел не только в письменную, но и в устную фольклорную традицию Польши того времени.

25 В рукописи BCzart1861, к примеру, представлен вариант с выдержанным изосиллабизмом: "I racz one posłać do Woyska Związkowego".

26 Напомним, что Ю. Новак-Длужевский пользовался для подготовки своей публикации тремя списками: Bran42/56, BK316 и BK361. 


\section{8. Перевод польского памсрлета "Pacierz dworski" в контексте русской культуры середины XVII В.}

Русский перевод пародии на «Отче наш» был сделан, по предположению С. М. Шамина, в 1671-1673 гг. Сразу заметим, что перевод памфлета "Pacierz dworski” на русский язык в это время уже теряет свою политическую актуальность: «...на русский язык его перевели после отречения Яна II Казимира, когда он уже не имел политического значения. Это еще раз подтверждает предположение, что внимание к пародии в значительной мере было связано с “курьезностью” текста», - считает Шамин [Шамин 2011: 109]. Политическая актуальность польской поэзии «на случай» для переводчиков Посольского приказа, как подчеркивает С. И. Николаев, в основном определялась упоминанием в ней России, и в этом случае она могла даже использоваться как «документ» в дипломатической практике [Николаев 2004: 87]. Хотя в памфлете “Pacierz dworski” и упоминается Москва, его перевод в Посольском приказе вряд ли был политическим решением. По мнению С. В. Алпатова и С. М. Шамина, для всех «отечественных реплик европейских памфлетов-пародий священных текстов» характерна «утрата социально-политической и конфессиональной злободневности» [Алпатов, Шамин 2012: 58]. Однако при этом они могли приобретать и новую социально-политическую функцию в русской культуре: для русского читателя мог представлять интерес сам факт смелой критики «действий верховной власти, критики, невозможной в условиях русской действительности» [Адрианова-Перетц 1936: 347].

Утрачивая злободневность, польские политические пародии в России приобретали и другую важную социально-культурную функцию. Напомним, что в Посольском приказе активно интересовались политической поэзией «на случай», так как, по словам С. И. Николаева, «именно она давала самый благодарный материал для изучения общественного мнения в Польше» [Николаев 2004: 87]. Кроме того, исследователь отмечает, что «памфлет “на потребу дня” иногда освещает те явления, которые не попадают в официозный отчет, да и появляется он зачастую быстрее» [Ibid.: 104]. Возможно, что перевод анализируемого памфлета имел подобное социально-культурное значение для Посольского приказа. При этом отметим, что "Pacierz dworski" - не единственный пример перевода в Посольском приказе 1670-х гг. сатирических стихов «на случай», посвященных исключительно внутриполитической ситуации в Речи Посполитой. Другим примером является сатирический цикл «Перевод с полского писма с виршов, каковы писаны на бесчестье королю полскому, и королеве, и послу францускому, и бискупом и сенаторем, а присланы те вирши чрез виленскую почту в нынешнем во $185<1676>$ 
году октября в 8 <день>» [Ibid.: 99-132]. Тексты обоих польских произведений относятся к солдатской поэзии и попали в Россию в рукописном виде. Как полагает С. И. Николаев, к появлению в России сатирического цикла мог быть причастен первый московский резидент в Варшаве B. М. Тяпкин, который «внимательно следил за литературными новинками» [Ibid.: 91]. Если предположить, что памфлет "Pacierz dworski” тоже попал в Москву благодаря Тяпкину, то он мог оказаться в России не ранее 1673 г., что, в принципе, не противоречит датировке перевода, данной С. М. Шаминым [2011: 107].

Не исключено, что основной причиной внимания русского читателя к польскому памфлету была именно его художественная сторона - пародийная структура. Переводчики Посольского приказа, как мы знаем, находили «элементы беллетристики даже в паралитературных сочинениях» [Małek 1978: 56]. Э. Малэк приводит многочисленные примеры извлечения для перевода отдельных беллетристических эпизодов из польских исторических хроник [Małek 1983: 14-19]. Исследовательница приходит к выводу, что большинство этих фрагментов к тому же связано с фольклором [Ibid.: 19]. В некоторой степени это касается и политической поэзии «на случай» и, возможно, обусловлено сознательным или бессознательным поиском общих, созвучных русской традиции, культурных референций.

Вне зависимости от причин интереса русского переводчика к памфлету, сам факт его перевода в России, по нашему мнению, повлек за собой смену функционального поля текста и переакцентирование его жанровой доминанты при рецепции. Появление сатиры "Pacierz dworski" связано с огромной значимостью политической публицистики в развитии конфликта между разными социальными слоями Польши того времени. По словам Ю. Новака-Длужевского, памфлеты являлись «бескровным оружием» политического противостояния [Nowak-Dłużewski 1953: XVIII]. Попав на русскую почву, даже при дословном переводе, эта пародия теряла идеологическую и социально-политическую актуальность за счет функциональных и жанровых сдвигов в культуре-реципиенте. На первый план здесь вышли социально-культурная и художественная функции текста. Название в переводе не сохранилось (или отсутствовало уже в польском рукописном источнике), таким образом памфлет "Pacierz dworski” превратился в пародию «Отче наш кроле полскии Яне Казимере», не испытав при этом никаких содержательных трансформаций благодаря пословному переводу. В целом же, как нам кажется, все польские переводные политические сатиры и пародии, не содержащие критики в адрес России, получают в русской культуре-реципиенте более выразительный смеховой контекст, в который может включаться и «смех над другим». 
Памфлет "Pacierz dworski” в русском переводе стоит у истоков русской переводной традиции польских юмористических произведений XVII ст. В России XVIII в. она стала настолько сильной, что, как отмечает Э. Малэк в отношении развития жанра стихотворных жарт, «анонимные авторы и переписчики стихотворных жарт приписывают польское происхождение текстам явно не польским» [Малэк 2008: 350]. Переведенная на русский пародийная молитва является также примером общности смеховой культуры поляков и русских. Одним из важных аспектов этой общности, по мнению Э. Малэк, было «родство на жанровом уровне», в том числе существование в обеих культурах «пародий на деловые жанры»: сатирических лечебников, пародийных молитв, служб, проповедей, посланий, челобитных и др. [Ibid.: 357-358]. Примем, однако, во внимание тот факт, что в русской переводной традиции XVII в. доминирует беллетристика западноевропейского Средневековья, а современные художественные произведения начинают переводиться только в середине следующего столетия [Małek 1978: 57]. Польская сатира «на случай», конкурируя в этом плане с «объемной» прозой, попадает в Россию часто вместе с актуальными документами, непосредственно после своего создания. Она закладывает основы для систематического интереса к польской современной литературе и публицистике, реализованного в многочисленных переводах с конца XVII в.

\section{9. Формально-содержательные особенности русского перевода}

Известные нам польские версии памфлета "Pacierz dworski” дают возможность заключить, что в Россию попала ранняя редакция текста. В русском переводе нет упоминания об отречении от престола Яна Казимира, которое появилось в более поздней редакции памфлета. Кроме того, сравнение списка памфлета из домашней хроники Ширмов (“Sylva rerum Szyrmów” ${ }^{27}$ и русского переводного текста позволяет предполагать их генетическую близость. Количество и порядок строк в них совпадают (40 полных строк) - за исключением явно ошибочной перестановки местами 14 и 15-го двустиший (о Тымфе и Боратини), нарушающей логический ход стиха в ширмовском списке. Переписчик их очевидно пропустил, но сразу же попытался исправить свою ошибку. В польском

27 Обратим внимание на то, что усадьба шляхетского рода Ширмов располагается на территории современной Беларуси, в Полесье. Там же, только южнее, на Волыни (современная Украина), размещалась и усадьба Я. Ерлича, а рукопись BCzart1861 является сборником Михаила Хлопицкого, проживавшего на территории современной Львовской области (Украина). Таким образом, география распространения памфлета охватывает центрально-южную часть Речи Посполитой. 
списке встречаются и другие ошибки и исправления (iako вместо ale, do Francyei вместо we Francyi, sztraznie вместо strasznie и др.). Русский перевод отражает правильную последовательность строк и «правильные», соответствующие большинству других польских списков формы и варианты слов. Поскольку практически все лексемы ширмовской версии отражены в русском переводе, можно предположить, что эти тексты могли иметь общий источник. Возможно, именно его копия и попала в середине XVII в. в Россию. Поэтому анализ русского перевода будет осуществлен с опорой именно на ширмовский список памфлета, носящий название "Pacierz o krolu polskim Janie Kazimirzu".

Перевод памфлета с польского на русский язык не мог вызвать больших трудностей у переводчика по причине простоты лексики и синтаксиса польского текста, отсутствия сложных фразеологических оборотов, латинских лексических вставок и других возможных препятствий для понимания содержания сочинения. Переводчик, однако, не ограничивается дословным отражением источника, а стилизует его при помощи церковнославянских лексико-грамматических форм.

Обращение к церковнославянским эквивалентам при переводе связано, возможно, и с универсальностью молитвенного текста. Сакральность «Отче наш» активировала в сознании русского переводчика не только молитвенные формулы, но и стилистически высокий регистр лексем и грамматических конструкций. Например, строка “Pozbawiłeś nas wszystkich powszedniego chleba” отражена в русском переводе как «Избавилъ еси нас всъ $x$ насущног(о) хлЊба», где кроме устойчивого словосочетания «насущног(о) хльба» употреблена форма перфекта со связкой «избавилъ еси». Формы аориста составляют мастерски подобранный аналог польской рифмы в строках 13-14: “żołnierzowi - gotowi” изменено на «оставихомъ - быхом». Подобная замена произведена и в предпоследнем двустишии, где польский восьмисложник “A zdrajcy wezmą zapłatę / Za tak straszno wielką stratę"28 переведен 14- и 12-сложными строками: «А измънникомъ будет равновоздаяние, / За их великои казны расточение». Впрочем, отмеченная неравносложность (невыдержанность изосиллабизма) характерна для всех строк русского перевода. При этом в найденных польских списках памфлета "Pacierz dworski" изосиллабизм также не всегда выдержан идеально, но стремление к нему однозначно. Невыдержанность изосиллабизма в русских переводах является характерной чертой поэтических переводов Посольского приказа [Николаев 2004: 106].

Отметим, что мастерство переводчика в подборе рифмы особенно проявляется во второй половине стиха, не скованной молитвенными

28 Bran42/56 - Za takowa wielka stratę. 
аллюзиями, что соотносится с вариативностью второй половины текста польского оригинала. Так, рифма “talery i orty” заменена на «орты ефимки» (с подбором русского эквивалента к «талеру») ${ }^{29}$, а в следующей строке к «ефимкам» была подыскана отсутствующая в польских вариантах рифма - полонизм «шинки». На то, что это именно замена, а не влияние неизвестного нам польского оригинала, указывает русское происхождение лексемы «ефимки». Из-за этой замены переводчик вынужден был изменить содержание всей строки оригинального текста: “Jako przed tym byli, za nas pelna kąty” ${ }^{0}$ в русском тексте звучит как «Которых исполнены были вездь шинки».

Все эти творческие находки переводчика, по сути, придают русскому переводу более возвышенную стилистику по сравнению с оригиналом и, как нам кажется, отражают опыт переводчика в работе с поэтическими текстами. Однако они контрастируют с остальной частью текста, пословно следующего польскому оригиналу. Это следование и множественные полонизмы приводят к появлению не совсем удачных рифм, которые воспринимаются такими именно на фоне поэтических находок переводчика.

Так, говоря о менее удачных решениях, С. М. Шамин отметил рифму «кролевскои - Францыи». Однако именно здесь мы видим, скорее, недосмотр переписчика. Сверив перевод с польскими версиями текста (в этих начальных строках они практически идентичны), мы обнаруживаем, что рифмоваться здесь должны “Szwecyjej - Francyjej”. В русском переводе это точно отвечает рифме «Швецыи - Францыи», а прилагательное «кролевскои» относится к следующей строке. По сути, благодаря отсутствию изосиллабизма и оставленным полонизмам, включительно с использованием польского ударения на предпоследнем слоге не только в полонизмах, но и в собственно русских словах, переводчику удается зарифмовать как точными, так и неточными рифмами весь памфлет. Исключение составляют пары двустиший, в которых переводчик не прикладывает усилий, чтобы подобрать слово с одинаковой заударной гласной: «Боратына - союзна», «червонны манеты».

Среди чуждых русскому языку XVII в. полонизмов отметим, прежде всего, лексемы «гуз» и «прехира», а также не употреблявшийся уже в живой речи вокатив «кроле». Последнее, однако, имеет в стихотворении грамматическое соответствие вокативу «отче», обусловленному текстом русской молитвенной формулы «Отче наш». К слову «гуз» переписчик на полях рукописи вынес пояснение - «удар», а значит, это слово было для

29 Ефимок - русское название европейских талеров.

${ }_{30}$ Bran42/56 - Jakie przed tym bywaty rozne zawsze sorty. 
него непонятным ${ }^{31}$. Поэтому и объяснение значения здесь - неточное, обусловленное контекстом: в старопольском языке «гуз» означал 'нарост', 'выпуклость' [Sst, 2: 523; Brückner 1927: 164]. Лексема «прехира» была употреблена в окружении имен собственных и давала мало возможностей для подбора альтернатив: «Ни Паца прехиры ни кота литвина» (пол. “Ani Paca przechiry, ani Kota Łatvyna”32). Значение слова «прехира» находим в словаре А. Брюкнера: «Прехыра, прехера, 'проныра, жулик’, общеупотребительное в XVI и XVII веке» [Brückner 1927: 441]. Отметим, что двустишие с именем литовского канцлера Паца встречается только в двух найденных нами польских списках памфлета (R113 и $B U W 74)$ и не было известно Ю. Новаку-Длужевскому.

\section{Заключение}

Польский памфлет-пародия “Pacierz dworski”, созданный около 1665 г. и направленный против короля Яна II Казимира Вазы, является типичным примером народной политической поэзии «на случай». Его пародийность основана на обращении к тексту молитвы «Отче наш», что придает ему, по сравнению с другими стихами времен рокоша Любомирского, особенную художественную ценность, даже несмотря на подражательный характер самой идеи использования молитвы и простоту языкового и стилистического решения. Использование жанра пародии и острота политической сатиры послужили причиной интереса к памфлету в Польше в течение нескольких столетий и, скорее всего, сыграли ключевую роль при выборе для перевода именно этого текста русским переводчиком Посольского приказа. Кто из приказных знатоков польского языка перевел памфлет, установить сложно, так как в начале 1670-х гг. их насчитывалось около десяти [Николаев 2004: 105]. Качество переводного текста, не лишенного буквализма и многих полонизмов, но и отражающего попытки литературной обработки оригинала, позволяет нам говорить о выраженной здесь типичной технике приказного перевода XVII в. Установка основных этапов ее развития в этот период требует, однако, дальнейшего исследования, с привлечением к анализу текстов как больших, так и малых форм.

31 «Словарь русских народных говоров» фиксирует пять значений слова «гуз», употребляемого в Псковских, Смоленских и Тверских говорах конца XIX начала XX в., но ни одно из них не имеет семантики удара [СРНГ, 7 1972: 206]. Среди них «гуз» в значении 'шишка (на лбу)', согласно «Новому словарю польских заимствований в русском языке» В. Витковского [Witkowski 2006: 39], является полонизмом. Это заимствование зарегистрировано, как показывает СРНГ, в псковских и смоленских говорах в 1919-1934 гг. [СРНГ, 7 1972: 206]. Перевод памфлета “Pacierz dworski” 1671-1673 гг. предоставляет пример более раннего употребления этой польской лексемы в русском языке.

32 BUW74 - Ani Paca Prochery Ni kota Litwina. 
Польский оригинал русского перевода в Посольском приказе, повидимому, не сохранили, но в результате сравнительного анализа известных нам вариантов памфлета с текстом русского перевода нами было выявлено, что русский перевод имеет очень близкую, возможно, даже генетическую связь со списком памфлета из домашней хроники Ширмов (“Sylva rerum Szyrmów”) [R113]. При этом русский перевод отражает более правильную, не известную в польских рукописях версию текста этого памфлета, которую легко можно восстановить, исходя из параллельного издания текстов, представленного ниже.

\section{Приложение. Параллельное издание польского и русского текстов}

В завершение мы предлагаем параллельное издание польского текста памфлета из домашней хроники Ширмов [R113] с приведением разночтений по другим спискам и русского перевода памфлета [РГАДА155] ${ }^{33}$. Общим принципом передачи польского и русского рукописных источников является максимально точное воспроизведение основного текста, дающее возможность его лингвистического анализа. Как основной текст, так и разночтения членятся на слова в соответствии со словоделением, принятым в современных польском и русском языках. Прописные буквы употребляются при передаче собственных и сакральных имен, а также, следуя источникам, в начале стихотворной строки.

При издании польского текста учитываются не только правила публикации старопольских произведений, принятые в польской текстологии с 1955 г. [Zasady 1955], но также и опыт более современных издательских серий “Biblioteka Pisarzy Staropolskich” и “Biblioteka Dawnej Literatury Popularnej i Okolicznościowej”, публикаторы которых исходят из языкового употребления конкретного автора и конкретных задач того или иного издания. Так, в данной статье нам кажется логичным ограничить сравнение семи польских вариантов текста подведением только смысловых и стилистических разночтений. Поэтому мы не учитываем некоторые графические, орфографические и пунктуационные особенности параллельных текстов: например, убирается повторная назализация (Jąie $\rightarrow$ Janie, mamy $\rightarrow$ mamy); длинное $\int$ транскрибируется как $s($ ieft $\rightarrow$ iest); снимается вариативное написание $y$ как $\ddot{y}$; не учитывается вариативность в написании расширенных и нерасширенных йотированных гласных в иностранных словах (Szwecyey и Szwecyiey).

33 Напомним, что русский перевод памфлета ранее был опубликован С. М. Шаминым [Шамин 2011]. Исходя из необходимости его параллельного издания с текстуально близким польским оригиналом, мы публикуем его еще раз, но с более точным воспроизведением орфографии и исправлением некоторых неточностей, допущенных в предыдущей публикации. 
Русский перевод, сделанный в Посольском приказе, публикуется с ориентацией на принципы передачи текста в новейшем издании «Вестей-Курантов» за 1671-1672 гг. [Вести-Куранты 2017: 30-48]. Например, воспроизводятся титловые сокращения с соответствующими диакритическими знаками классического титла; выносные буквы вносятся в строку и выделяются курсивом, при этом покрытия над ними не воспроизводятся. (Акцентные знаки отсутствуют в нашем рукописном источнике.) Однако варианты скорописных начертаний «і десятеричного» $(i$ и $i)$ сохраняются, как и графемы $i$ (на месте $j$ ) и $y$ (на месте $j, i)$ в польском основном тексте.

Поскольку и польский, и русский тексты в их источниках разбиты на двустишья (польский - с помощью написания второй строки в строфе с отступлением, русский - с использованием пустой строки между строфами), в издании строфы разделяются увеличенными интервалами; конец строки отмечается знаком | только в случаях, когда он не совпадает с концом стихотворной строки.

$\mid$ s. 32|

Pacierz o królu polskim Janie Kazimirzu

Oycze nasz krolu polski ${ }^{34}$ Janie Kazimirzu ${ }^{35}$. Ktory iest na maiestacie, lecz nie $\mathrm{w}$ dobrym pierzu

Swięc sie imie twoie iako ${ }^{36}$ we Szwecij3

A krolowy Ludwiki takze do Francyei. ${ }^{38}$ $\mid$ s. 33|

${ }_{5}$ Przydz raczey do krolestwa swego

Szwedzkiego.

A nie obracay w niwecz naszego Polskiego. Bądz wola twoia iako Wandalu ${ }^{39}$ była. |л. 29|

Перевод с полского писма, |

Отче н̈шъ кроле полскиї Ане Казимере Сыи на прстле но не в добромъ пере,

Светис имя твое, но в Швецыї кролевскои Людвики, також во Францыї,

Приїди лутче х королевству твоему | Свъискому, А не дъвлай | гибели нашему Полскому, $W$ дабы воля твоя в Вандале $x$ была, Гдъ хлъба мало. а селдей великая | сила,

34 Слова krolu polski наведены поверх других как исправление, скорее всего, неправильного порядка слов (под исправлениями угадываются слова polski krolu).

35 Во всех других вариантах - Kazimierzu. Поскольку форма Kazimirzu повторяется и в названии, возможно, ее следует рассматривать не как ошибочную, а как специфическую для диалекта переписчика. Ср. вариант żotnirzowi в строке 13.

36 В других вариантах - ale, чему в русском переводе отвечает но.

37 Во всех других шести вариантах находим иное падежное окончание - we Szwecyjej (варьируется только орфографическое написание).

38 В других списках - we Francyjej (орфография варьируется), ср. русский перевод.

39 Bran42/56, BCzart1861, BK361 - w Wandaliey; Ерлич - w Wandalii (здесь и далее в сносках цит. по изданию 1916), см. также русский перевод; другие, очевидно, ошибочные: BK316 - w Kandaliey; BUW74 - w Kurlandyey.

${ }^{40}$ Bran42/56 - a snadz; BCzart1861, BUW74 - a znac; BK361 - ale; BK316 - tylko.

41 У Ерлича строка звучит так: Kiedy byto mato chleba, a ludzi sita. 


\begin{tabular}{|c|c|}
\hline Odpusc nam nasze winy pogłowne & $\begin{array}{l}\text { Не веди на королевство так } \\
\text { Не можемъ бо | терпьти то. } \\
\text { Ня жек г } \\
\text { ти намъ ты желай }\end{array}$ \\
\hline
\end{tabular}

${ }^{42}$ Bran42/56 - rzeczy iakies; BK361 - rzeczy bardzo. Во всех остальных так, как в ширмовской.

43 Во всех других, кроме Ерлича, - o wolnosci. У Ерлича этой строки нет.

44 Так же - у Ерлича и в Bran42/56. BUW74 - A nie; BCzart1861, BK316, BK361 - Inie.

45 Bran42/56, ВK316, ВK361-dość. В остальных - dosyć.

46 Во всех других версиях, кроме ерличевской и ВK361, повторяется предлог $z$ (z Kozakami). В рукописи BK361 ошибочно списано окончание с предыдущей строки, но во втором случае исключен повтор предлога (Gdyz mamy dosć zabawy z Szwedy Francuzami). У Ерлича - Bo mamy kłopotu dosyć z Ordą i kozakami.

47 Bran42/56, BCzart1861, BUW74, BK316, Ерлич - wprowadzay; BK361 przyprowadzay.

48 ВK361, ВUW74, Ерлич - нет.

49 В других нет. Вероятно, вписано по аналогии со второй строкой следующего двустишия. У Ерлича - owo (Bo owo zgoła nie ścierpiemy takowego guza).

${ }^{50}$ Bran42/56, BK316, BK361, BUW74 - nie możemy; BCzart1861 - nie będziemy.

51 Bran42/56, BCzart1861, ВК316, ВK361 - wielkiego; ВUW74 - ciężkiego; Ерлич см. ссылку 49.

52 На поле листа тем же почерком приписано ударъ.

53 Bran42/56 - zyczyc wiecey; BCzart1861 - nażyczay więcey. У Ерлича этого двустишия нет.

${ }^{54}$ Во всех других - Kondeusza (Condeusza).

55 Bran42/56, BUW74 - Gdysz go cale nie lubi strasznie nasza dusza; BK316 - Gdyż go cale nie lubi nasza polska dusza; BCzart1861, BK361 - Bo go strasznie nie lubi cale nasza dusza. 


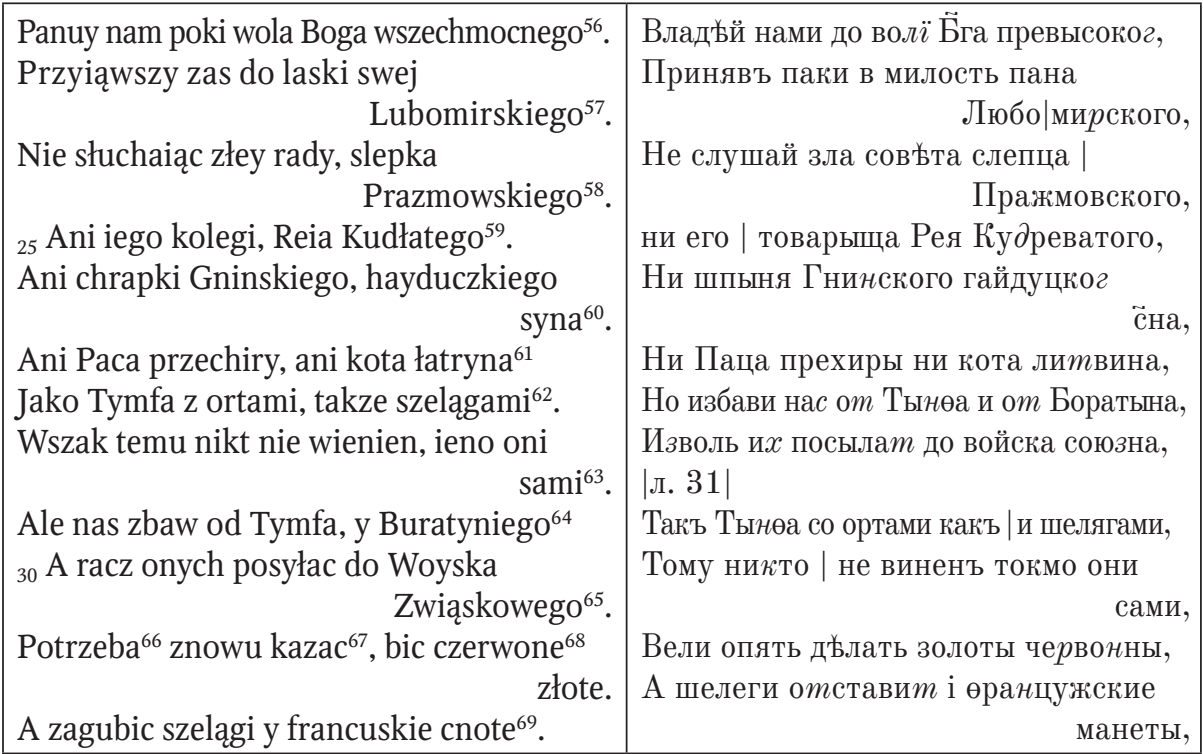

${ }^{56}$ BK316 - naywyszszego; ср. русский перевод. У Ерлича этой строки нет.

57 Bran42/56 - Przyjąwszy do łaski swey P: Lubomirskiego; Ерлич - Przyimij do łaski swey pana Lubomirskiego.

58 Ерлич - Nie stuchay rady slepego Prażmowskiego.

59 BCzart1861 - Paca Kudtatego. У Ерлича этой строки нет.

${ }^{60}$ Bran42/56 - Ani franta Gninskiego ktory szkody szuka; BCzart1861 - Ani franta Gninskiego, ktory zdrady szuka; BUW74 - Ani franta Gninskiego hayduckiego syna. B остальных - нет.

${ }^{61}$ Bran42/56 - Oyczyzny naszey bo snac miat oyca hayduka; BCzart1861 - Oyczyzny naszey bo znad co miat oyca hayduka; BUW74 - Ani Praca Prochery ni kuta Lituina.

62 Эта строфа и следующая ошибочно переставлены местами. Правильный порядок ср. по русскому переводу. BCzart1861 - I te tymphy z ortami, takze z szelagami; BK316 - Bo kto z Tynfom z ortami takze z szelagami. У Ерлича начало этой строки соединено с концом другой, см. ссылку 64.

63 Bran42/56, BUW74 - tylko вместо ieno; BK361 - Bo temu nikt nie winien tylko oni sami; BCzart1861 - Bo temu nikt nie winien telko (tak!) waszec sami; BK316 - Nikt naybardziey nie winien tylko oni sami. У Ерлича этой строки нет.

${ }^{64}$ Bran42/56, BCzart1861, BK316, BK361 - Boratyniego; Ерлич - Tynfy z ortami, szelagami Boratynego.

${ }^{65}$ Bran42/56 - I racz onych odestac do Woyska Zwiaskowego; BCzart1861 - I racz one posłac do Woyska Zwiaskowego; BUW74 - A racz ich poslać do Woyska Zwiazkowego; BK316 - I poszli ich do czarta piekła przeklętego; BK361 - Odeslii ich do czarta obo przeklętego; Ерлич - Odeszli ich kendy do czarta przeklętego.

${ }^{66}$ Bran42/56, BCzart1861, BK361 - Dobrze by; BK316 - Stusznie by; BUW74 - Dobrze. У Ерлича этой строки нет.

67 BUW74 - нет.

68 BUW74 - o czerwone.

69 Вместо y francuskie cnote: Bran42/56 - francuska niecnotę; BK316 - przemierzła hototę; BK361 - przemierztą robotę. У Ерлича этой строки нет. 


\begin{tabular}{|c|c|}
\hline $\begin{array}{l}\text { Kaz znowu dobre robic }{ }^{70} \text { talary y orty }{ }^{71} \\
\text { Jako przed tym byli, za nas pelna kąty }{ }^{72} \\
\text { Przywroc do Korony tesz srebro y } \\
\text { złoto }^{73} \text {. } \\
\text { Bo kiedy kolwiek, będzie kłopot o to }{ }^{74} \text {. } \\
\text { A zdrayce wezmu }{ }^{75} \text { zapłate }^{76} \text {. } \\
\text { Za tak strazno wielką strate }{ }^{77} \text {. } \\
\text { Amen amen miły panie }{ }^{78} \text {. } \\
{ }_{40} \text { Niech sie tak wrychle stanie }^{79} \text {. }\end{array}$ & $\begin{array}{l}\text { Вели опять дълать орты еөилки, } \\
\text { Которы } x \text { исполнены были вездъ шинки, } \\
\text { Приврати паки }{ }^{80} \text { в коруну сребро і } \\
\text { злато, } \\
\text { Буде } m \text { бо велика бъда нъкогда за то, } \\
\text { А измънникомъ буде } m \text { равновоздаяние, } \\
\text { За и } x \text { великои казны расточение, } \\
\text { Аминь аминь любезныї гсдрь, } \\
\text { Сей бедъ какъ скоръе предварь. }\end{array}$ \\
\hline
\end{tabular}

\section{Библиограсрия}

\section{Архивные источники}

\section{BK316}

Biblioteka Kórnicka (Poznań), № 316, Miscellanea, w tym: tzw. Rokosz Gliniański, Rokosz Mikołaja Zebrzydowskiego, Jerzego Lubomirskiego, spory Stanisława Stadnickiego z Łukaszem Opalińskim, wojna z Moskwą, bunty żołnierstwa najemnego, na okładce.

70 Bran42/56 - robic dobre.

71 BCzart1861 - Kaz waszec znowu robic talery y orty; BUW74 - Kasz dobrze robic talery y orty; BK316 - Kaz znowu robic dobre orty y talery; BK361 - Rozkazac znowu robic orty y talery; Ерлич - Przywróć nam stare orty i talary (эта строфа вставлена сразу после Nie stuchay rady ślepego Prażmowskiego, см. ссылку 58).

${ }^{72}$ Bran42/56 - Jakie przed tym bywaty rozne zawsze sorty; BCzart1861 - Zanich przed tym bywaly dobre zawsze forty (tak!); BUW74 - Jakiesz zawsze bywali pelne nasze sorty; BK316 - Ktorezmi nie szezycili polscy kawalery; Ерлич - Jako przed tym w Polszcze za innych bywaly.

${ }^{73}$ Bran42/56, BUW74 - Przywrocic do Korony kasz srebro y złoto; BCzart1861, BK316 Przywroc nam do Korony nasze srebro, złoto; BK361 - Przywrocic do Korony zas srebro y złoto; Ерлич - Przywróć nam srebro i złoto.

${ }^{74}$ Bran42/56, BUW74 - Bo kiedy kolwiek będzie straszny ktopot o to; BCzart1861 - Bo kiedyz kolwiek straszny będzie ktopot o to; BK361 - Bo będzie kiedysz kolwiek straszny kłopot o to; ВK316 - Bo wiedz o tym ze będzie wielki kłopot o to (ср. велика бпда в русском переводе); Ерлич - Bo po śmierci będziesz w piekle miat kłopot o to.

75 Bran42/56 - wezma.

76 BCzart1861 - I straisi z waszeciami wezma swa zaplatę. В других - нет.

77 Bran42/56 - Za takowa wielka stratę; BCzart1861 - Za taka nas koronnych szlachty wielka stratę. В остальных - нет.

78 Ерлич - O móy mity panie!

${ }^{79}$ Bran42/56 - Niech ze sie to wrychle stanie; BCzart1861 - Niechay sie tak wkrotce stanie; Ерлич - Niech że się tak stanie! - Amen. BK316 (на месте последнего двустишия) - Już o to wszystko trudno. Pacierza nie sprostat, | Uczyc się od Polakow, Abdykantem zostat.

80 Русское паки может быть переводом польского zaś, отсутствующего в ширмовской версии, но имеющегося в источнике перевода, и, например, в $B K 361$, ссылка 73; ср. польский текст и перевод в строке 22: Przyiąszy zas - Принявъ паки. 
BK361

Biblioteka Kórnicka (Poznań), № 361, Compendium tractatow woyskowych y punctow na seymach uchwalonych roznych takze expedicyi woyskowych y listow roznych y godnych terminowania roznymi czasy zebrane roku panskiego 1655, 1655-1667, 175.

Bran $42 / 56$

Archiwum Główne Akt Dawnych, Zbiór Branickich z Suchej, № 42/56, 449.

BUW74

Biblioteka Uniwersytetu Warszawskiego, № 74, Kopiariusz korespondencji i akt spisany dla

Stanisława Godlewskiego, starosty Nurskiego, z lat 1690-1702, 260-261.

BCzart1861

Biblioteka Książąt Czartoryskich, № 1861, Zbiór mów, listów oraz satyr i pamfletów politycznych, sporządzony przez Michała Chłopickiego skarbnika żydaczowskiego, w latach 1700-1709, 30-31.

R113

Biblioteka im. Zielińskich Towarzystwa Naukowego Płockiego, ze zbiorów Władysława Smoleńskiego, № R113, “Sylva rerum Szyrmów 1667-1732”, 32-33.

РГАДА155

Российский государственный архив древних актов. Ф. 155. Иностранные ведомости (куранты) и газеты - (коллекция) из фондов Посольского приказа и Коллегии иностранных дел.

\section{Литература}

Адрианова-Перетц 1936

Адрианова-Перетц В. П., «Образцы общественно-политической пародии XVIII - нач. XIX в.», in: Труды Отдела древнерусской литературы, 3, 1936, 335-366.

Алпатов, Шамин 2012

Алпатов С. В., Шамин С. М., «Влияние европейских памфлетов-пародий на формирование русской традиции раrodia sacra XVII-XIX вв.», in: Вестник Московского университета, Серия. 9. Филология, 2, 2012, 58-66.

$-2013$

Алпатов С. В., Шамин С. М., «Европейский юмор в России XVII в.», Древняя Русъ.

Вопросы медиевистики, 4, 2013, 21-33.

Вести-Куранты 2017

«Принципы воспроизведения и комментирования текста. Передача акцентных и прочих диакритических знаков. Передача знаков пунктуации», in: Вести-Куранты. 16711672 г2., Москва, 2017, 30-48.

Возняк 1931

Возняк М. С., «Українські пісні й польські вірші з “Літописця” Єрлича», in: Записки НТШ, 151, Львів, 1931, 195-205.

Ерлич 1916

«Летопись Иоахима Ерлича (1620-1673 гг.), Latopisiec albo Kroniczka różnych spraw i dziejów dawnych i terazniejszych czasów», [in: Южнорусские летописи], Левицкий О. И., [ред.], Киев, [1916?], 34-393.

Малэк 2008

Малэк Э., Разыскания по русской литературе XVII-XVIII вв.: Забытые и малоизученные произведения, С.-Петербург, 2008.

Николаев 1992

Николаев С. И., «Из истории польской сатирической литературы в России (XVII - первая половина XVIII в.)», in: Труды Отдела древнерусской литературы, 45, 1992, 305-314. 
2004

Николаев С. И., «Поэзия и дипломатия (Из литературной деятельности Посольского приказа в 1670-х гг.)», in: Николаев С. И., От Кохановского до Мицкевича: Разыскания по истории польско-русских литературных связей XVII - первой трети ХIX в.,

С.-Петербург, 2004, 86-132.

$-2008$

Николаев С. И., Польско-русские литературные связи XVI-XVIII вв.: Библиографические материалы, С.-Петербург, 2008.

СРНГ, 71972

Словарь русских народных говоров, 7, Ленинград, 1972.

Тесленко 2004

Тесленко I. А., «Родинний клан Єрличів», in: Соціум. Альманах соціальної історії, 4, Київ, 2004, 135-188.

Шамин 2011

Шамин С. М., «Польский политический памфлет в России XVII столетия: пародийная переделка молитвы “Отче наш” из дела с курантами 1672 г.», in: Древняя Русъ. Вопросы медиевистики, 1, 2011, 107-111.

Яковенко 2012

Яковенко Н. М., «Життєпростір versus ідентичність руського шляхтича XVII століття (на прикладі Яна/Йоакима Єрлича)», in: Яковенко Н., Дзеркала ідентичності. Дослідження 3 історії уявлень та ідей в Україні XVI - початку XVIII століття, Київ, 2012, 63-104.

Bartoszewicz 1877

Bartoszewicz J., Historja literatury polskiej potocznym sposobem opowiedziana, II, Kraków, 1877.

Brückner 1927

Brückner A., Stownik etymologiczny języka polskiego, Kraków, 1927.

Burde 2010

Burde M., "The Parodia sacra Problem and Medieval Comic Studies”, in: Laughter in the Middle Ages and early modern times: epistemology of a fundamental human behavior, its meaning, and consequences, Classen A., ed., New York, 2010, 215-242.

Choroszy 2008

Ojcze nasz - nasz: Przekłady, parafrazy i inne literackie opracowania Modlitwy Pańskiej, Choroszy Jan A., oprac., 1-2, Wrocław, 2008.

Czubek 1916

Pisma polityczne z czasów rokoszu Zebrzydowskiego 1606-1608: Poezja rokoszowa, 1, Czubek J., wyd., Kraków, 1916.

Dziewanowski-Stefańczyk 2017

Dziewanowski-Stefańczyk B., "Tytus Liwiusz Boratyni i znaczenie nowych emisji monety”, in: Mówia Wieki, 2 (685), 2017, 77-80.

Grzeszczuk 1966

Grzeszczuk S., “Wstęp”, in: Antologia literatury sowiźrzalskiej XVI i XVII wieku, Wrocław Warszawa - Kraków, 1966, 1-140.

Hniłko 1910

Hniłko A., "Szczegół z literatury o tymfach i szelągach”, Wiadomości NumizmatycznoArcheologiczne, 2, 1910, 1-3.

Jerlicz 1853 Jerlicz J., Latopisiec albo Kroniczka różnych spraw i dziejów, z rękopismu, wyd. K. Wójcicki, Warszawa / St. Petersburg, 1853, 103-105. 
Krzywy 2018

Krzywy R., “Wstęp. W kręgu poezji okolicznościowej”, in: Jan Kochanowski. Poematy

okolicznościowe, Krzywy R., oprac., Warszawa, 2018, 5-71.

Łoś 2000

Łoś J., Pamiętnik towarzysza choragwi pancernej, Śreniawa-Szypiowski R., oprac., Warszawa, 2000.

Małek 1978

Małek E., Historia o Meluzynie. Z dziejów romansu rycerskiego na Rusi, Bydgoszcz, 1978. 1983

Małek E., Staropolska proza narracyjna w procesie literackim Rosji wieku XVII i XVIII, Łódź, 1983.

Nowak-Dłużewski 1953

Nowak-Dłużewski J., Poezja Związku Święconego i rokoszu Lubomirskiego, Wrocław, 1953. 1967

Nowak-Dłużewski J., Z historii polskiej literatury i kultury, Warszawa, 1967. 1972

Nowak-Dłużewski J., Okolicznościowa poezja polityczna w Polsce: Dwaj młodsi Wazowie, Warszawa, 1972.

Pamiętniki 1858

Pamiętniki Łosia, towarzysza chorąwi pancernéj Władystawa margrabi Myszkowskiego wojewody krakowskiego, obejmujące wydarzenia od r. 1646 do 1667, z rękopismu wspótczesnego, dochowanego w zamku podhoreckim, wydane, Kraków, 1858.

Pietrzyk 2008

Pietrzyk P., “'Chleba naszego powszedniego zbawiłeś nas za panowania swego...' - o parodiach tekstów religijnych w literaturze XVII i XVIII stulecia”, in: NAPIS, 14, 2008, 57-69.

Sst, 2

Stownik staropolski, 2: D-H, Wrocław - Kraków - Warszawa, 1956-1959.

Śreniawa-Szypiowski 2000

Śreniawa-Szypiowski R., “Wstęp”, in: Łoś J., Pamiętnik towarzysza choragwi pancernej, ŚreniawaSzypiowski R., oprac., Warszawa, 2000, 5-50.

Witkowski 2006

Witkowski W., Nowy stownik zapożyczeń polskich w języku rosyjskim, Kraków, 2006.

Zachara 1981

Zachara M., "Silva Rerum Szyrmów”, in: Odrodzenie i reformacja w Polsce, XXVI, 1981, 161-177.

Zasady 1955

Zasady wydawania tekstów staropolskich, Woronczak J., Górski K., eds., Wrocław, 1955.

\section{References}

Adrianova-Peretts V. P., "Obraztsy obshchestvenno-politicheskoi parodii XVIII - nach. XIX v.", in: Trudy Otdela drevnerusskoi literatury, 3, 1936, 335-366.

Alpatov S. V., Shamin S. M., "Vliianie evropeiskikh pamfletov-parodii na formirovanie russkoi traditsii parodia sacra XVII-XIX vv.", in: Moscow State University Bulletin. Series 9. Philology, 2, 2012, 58-66.

Alpatov S. V., Shamin S. M., "The European Humor in Russia in the 17th cent”, in: Old Russia. The Questions of Middle Ages, 4, 2013, 21-33.

Brückner A., Stownik etymologiczny języka polskiego, Kraków, 1927.
Burde M., "The Parodia sacra Problem and Medieval Comic Studies", in: Laughter in the Middle Ages and early modern times: epistemology of a fundamental human behavior, its meaning, and consequences, Classen A., ed., New York, 2010, 215-242.

Choroszy Jan A., ed., Ojcze nasz - nasz: Przekłady, parafrazy $i$ inne literackie opracowania Modlitwy Pańskiej, 1-2, Wrocław, 2008.

Dziewanowski-Stefańczyk B., "Tytus Liwiusz Boratyni i znaczenie nowych emisji monety”, in: Mówiq Wieki, 2 (685), 2017, 77-80. 
Grzeszczuk S., "Wstęp", in: Antologia literatury sowiźrzalskiej XVI i XVII wieku, Wrocław - Warszawa - Kraków, 1966, 1-140.

Krzywy R., "Wstęp. W kręgu poezji okolicznościowej", in: Jan Kochanowski. Poematy okolicznościowe, Krzywy R., ed., Warszawa, 2018, 5-71.

Łoś J., Pamiętnik towarzysza choragwi pancernej, Śreniawa-Szypiowski R., ed., Warszawa, 2000.

Małek E., Historia o Meluzynie. Z dziejów romansu rycerskiego na Rusi, Bydgoszcz, 1978.

Małek E., Razyskaniia po russkoi literature XVIIXVII vv.: Zabytye i maloizuchennye proizvedeniia, St. Petersburg, 2008.

Małek E., Staropolska proza narracyjna w procesie literackim Rosji wieku XVII i XVIII, Łódź, 1983.

Nikolaev S. I., "Iz istorii pol'skoi satiricheskoi literatury v Rossii (XVII - pervaia polovina XVIII v.)", in: Trudy Otdela drevnerusskoi literatury, 45, 1992, 305-314.

Nikolaev S. I., "Poeziia i diplomatiia (Iz literaturnoi deiatel'nosti Posol'skogo prikaza v 1670-kh gg.)", in: Nikolaev S. I., Ot Kokhanovskogo do Mitskevicha: Razyskaniia po istorii pol'sko-russkikh literaturnykh sviazei XVII - pervoi treti XIX v., St. Petersburg, 2004, 86-132.

Nikolaev S. I., Pol'sko-russkie literaturnye sviazi XVI-XVIII vv.: Bibliograficheskie materialy, St. Petersburg, 2008.

Nowak-Dłużewski J., Okolicznościowa poezja polityczna w Polsce: Dwaj mtodsi Wazowie, Warszawa, 1972.

Nowak-Dłużewski J., Poezja Zwiazku Święconego i rokoszu Lubomirskiego, Wrocław, 1953.
Nowak-Dłużewski J., Z historii polskiej literatury i kultury, Warszawa, 1967.

Pietrzyk P., "'Chleba naszego powszedniego zbawiłeś nas za panowania swego...' - o parodiach tekstów religijnych w literaturze XVII i XVIII stulecia”, in: NAPIS, 14, 2008, 57-69.

Shamin S. M., "Pol'skii politicheskii pamflet $\mathrm{v}$ Rossii XVII stoletiia: parodiinaia peredelka molitvy "Otche nash" iz dela s kurantami 1672 g.", in: Old Russia. The Questions of Middle Ages, 1, 2011, 107111.

Śreniawa-Szypiowski R., "Wstęp”, in: Łoś J., Pamiętnik towarzysza choragwi pancernej, ŚreniawaSzypiowski R., ed., Warszawa, 2000, 5-50.

Teslenko I. A., "Rodynnyi klan Erlychiv", in: Sotsium. Al'mahakh sotsial'noii istoriii, 4, Kiev, 2004, 135-188.

Voznyak M. S., "Ukraiins'ki pisni i pol's'ki virshi z 'Litopysts'a' Erlycha”, in: Zapiski NTSH, 151, Lviv, 1931, 195-205.

Witkowski W., Nowy stownik zapożyczeń polskich w języku rosyjskim, Kraków, 2006.

Woronczak J., Górski K., eds., Zasady wadawania tekstów staropolskich, Wrocław, 1955.

Yakovenko N. M., "Zhytteprostir versus identychnist' rus'kogo shliakhtycha XVII stolittia (na prykladi Iana/Ioakyma Erlycha)", in: Dzerkala identychnosti. Doslidzhennia $z$ istoriii uiavlen' ta idei $v$ Ukraiini XVI - pochatku XVIII stolittia, Kiev, 2012, 63-104.

Zachara M., "Silva Rerum Szyrmów", in: Odrodzenie i reformacja $w$ Polsce, 26, 1981, 161-177.

\section{Olena Jansson,}

doktorand i Slaviska språk,

Uppsala universitet, Institutionen för moderna språk

Box 636, SE - 75126 Uppsala

Sverige/Sweden

Olena.Jansson@moderna.uu.se

Received June 10, 2018 